\title{
Belgeo
}

Revue belge de géographie

$4 \mid 2001$

Miscellaneous

\section{Hot spot analyse in de praktijk : illustraties aan de hand van het fenomeen woninginbraken in het arrondissement Turnhout}

Hot-spot analysis in practice: an illustration by means of the house breaking phenomenon in the arrondissement of Turnhout

\section{Robbie Heremans}

\section{OpenEdition \\ Journals}

Édition électronique

URL : https://journals.openedition.org/belgeo/15675

DOI : 10.4000/belgeo.15675

ISSN : 2294-9135

\section{Éditeur :}

National Committee of Geography of Belgium, Société Royale Belge de Géographie

\section{Édition imprimée}

Date de publication : 30 décembre 2001

Pagination : 351-376

ISSN : 1377-2368

Référence électronique

Robbie Heremans, «Hot spot analyse in de praktijk : illustraties aan de hand van het fenomeen woninginbraken in het arrondissement Turnhout», Belgeo [Online], 4 | 2001, Online op 31 décembre 2001, geraadpleegd op 16 novembre 2021. URL: http://journals.openedition.org/belgeo/15675 ; DOI: https://doi.org/10.4000/belgeo.15675

Ce document a été généré automatiquement le 16 novembre 2021.

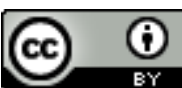

Belgeo est mis à disposition selon les termes de la licence Creative Commons Attribution 4.0 International. 


\title{
Hot spot analyse in de praktijk : illustraties aan de hand van het fenomeen woninginbraken in het arrondissement Turnhout
}

\author{
Hot-spot analysis in practice: an illustration by means of the house breaking \\ phenomenon in the arrondissement of Turnhout
}

Robbie Heremans

1 De analyses van criminele " hot spots " (« haarden », ruimtelijke concentraties) en «burning times» («piekmomenten», temporele concentraties) zijn belangrijk geworden voor het werk van criminologen, strategisch analisten bij politiediensten en preventiewerkers. Het is al lang geweten dat de criminaliteit niet gelijkmatig is gespreid in spatio-temporeel opzicht. Deze vaststelling in de negentiende eeuw wordt zelfs beschouwd als de aanleiding tot het ontstaan van de criminologie als wetenschap. Studies over de spreiding van criminaliteit handelden in het verleden echter bijna uitsluitend over de ruimtelijke concentratie van verblijfplaatsen van criminelen.

Brantingham en Brantingham (1999) stellen dat het onder andere de opkomst is van de " environmental criminology", de criminologische stroming met bijzondere interesse voor de omgevingsfactoren die criminele feiten genereren en faciliteren, die ervoor heeft gezorgd dat ook de ruimtelijke concentraties van criminele feiten de nodige aandacht kregen. Meermaals is aangetoond dat criminele feiten eerder ruimtelijk geconcentreerd zijn dan dat zij worden gepleegd door dezelfde daders ${ }^{1}$ zodat de plaatsof situatiegerichte aanpak van criminaliteit zeker zijn plaats verdient naast de dadergerichte aanpak. Ook technologische evoluties zoals de automatisering van politionele gegevensbanken, de verspreiding van goedkope, krachtige personal computers met uitgebreide mogelijkheden op het gebied van cartografie en de ontwikkeling van software voor ruimtelijke analyse en GIS (Geografisch Informatie Systeem) hebben bijgedragen tot de toegenomen belangstelling voor hot spots zodat 
deze term zijn plaats heeft verworven in de dagelijkse woordenschat van tactische en strategisch analisten.

\section{Definities van hot spots}

Sherman (1995) definieert een hot spot als «small places in which the occurence of crime is so frequent that it is highly predictable, at least over a 1-year period». Brantingham en Brantingham (1999) omschrijven een hot spot als «spatial concentrations or clusters of crime that are visually recognizable to an observer looking at reasonable pictures or maps of criminal events, or that are mathematically recognizable through analysis of crime occurrence locations ».

Terwijl Sherman dus enigszins de nadruk legt op de voorspelbaarheid van de criminele feiten in een hot spot, geven de Brantinghams meer aandacht aan de methodes die de hot spots bepalen : het bestuderen van kaarten of (statistische) analytische methodes. Hot spots worden (h)erkend ( recognize ») door een waarnemer of techniek en krijgen daarom dat bepaalde etiket. Dit impliceert dat er geen absolute norm is voor het bepalen van de grenzen rond de verzameling van feiten die een hot spot bepalen. Deze grens wordt bepaald door de analist of techniek die een vorm van synthese tracht te realiseren in een complexe werkelijkheid. In realiteit zal de concentratie van feiten eerder gradueel afnemen. Een aantal critici van hot spot analyse opperen bovendien dat hot spots louter een effect zijn van de schaal waarmee het bestudeerde grondgebied wordt weergegeven. Inderdaad, men kan een clustering van feiten zodanig uitvergroten dat er zowel op visueel als op statistisch vlak geen sprake meer is van een clustering.

Om deze redenen volstaat het ons inziens om een heel algemene definitie te hanteren : «ruimtelijke concentraties waar gedurende een bepaalde periode een hoog of verhoogd aantal of risico van criminele feiten wordt vastgesteld». Het is tijdens de operationalisering van deze definitie dat de onderzoeker zal expliciteren wat tijdens een bepaald onderzoek wordt verstaan onder de term "hot spot» en het zal deze explicitering zijn die zal bepalen waar de hot spots en de grenzen van de hot spots gelegen zijn. De onderzoeker dient in het onderzoeksrapport dus uitdrukkelijk de operationalisering van het concept hot spot te vermelden zodat het ook voor de lezer duidelijk is wat wordt verstaan onder « ruimtelijke concentratie ", « hoge of verhoogde frequentie » en wat het bestudeerde tijdsinterval is. Dit is ook een van de redenen waarom wij eerder de voorkeur geven aan de statistische methodes dan aan de meer intuïtieve methodes zoals het bestuderen van kaarten. Bij de statistische methodes volstaat het meestal om de gehanteerde parameters te vermelden terwijl de beschrijvingen van de intuïtieve methodes moeilijker en minder accuraat zullen zijn.

\section{Gegevens}

De verschillende methodes voor de identificatie van hot spots zijn geillustreerd met gegevens van woninginbraken in het arrondissement Turnhout in 2000. In 2000 werden er 2762 inbraken gepleegd in het arrondissement Turnhout ${ }^{2}$. Dit betekent dat bijna 1 huisgezin op 50 (meer bepaald 18 huisgezinnen op 1000) slachtoffer is geworden van een woninginbraak ${ }^{3}$. 
7 Voor de geografische analyse zijn de feiten geografisch gecodeerd (of « gegeocodeerd ») tot op het niveau van de straat waar de feiten zijn gepleegd. Dit betekent dat aan elk feit de X- en Y-coördinaten zijn toegekend van het centrale punt ${ }^{4}$ van de straat waar het feit heeft plaatsgevonden. De nauwkeurigheid van de analyse is met andere woorden beperkt tot op het niveau van de straten.

\section{Globale testen van clustering}

8 Vooraleer concentraties van feiten te bepalen, is het zinvol om na te gaan of er in algemene termen wel sprake is van clustering bij de gegevens. Zoals hierboven reeds werd vermeld, zijn $50 \%$ van de vastgestelde woninginbraken gepleegd in $5 \%$ van het totale stratenbestand. Dit kan worden beschouwd als een aanduiding van clustering.

9 Een andere eenvoudige manier om na te gaan of de gegevens geclusterd zijn is de Nearest Neighbour Index (NNI). De NNI vergelijkt de geobserveerde ruimtelijke spreiding met een spreiding volgens het toeval van hetzelfde aantal feiten over hetzelfde grondgebied. De gemiddelde afstand tussen de punten van de geobserveerde gegevens wordt vergeleken met de gemiddelde afstand die men verwacht wanneer de feiten volledig volgens het toeval zouden zijn verdeeld over het grondgebied. Als het resultaat van de NNI test ongeveer gelijk is aan 1 dan zijn de feiten min of meer volgens het toeval verdeeld. Een NNI die kleiner is dan 1 wijst op clustering van de gegevens. Een NNI die groter is dan 1 wijst op een meer dan normale gelijkmatige spreiding van de feiten over het grondgebied. De NNI is echter enkel geschikt om de ruimtelijk concentratie van puntgegevens te toetsen en niet van geaggregeerde gegevens. Aangezien de gegevens met betrekking tot de woninginbraken in het arrondissement Turnhout geaggregeerd zijn op het niveau van de straten, laat de NNI enkel toe om de concentratie van feiten op een zeer strenge manier te toetsen : de 2762 feiten worden gereduceerd tot 1430 punten (middelpunten van straten waar 1 of meerdere feiten zijn gepleegd) zodat er geen rekening wordt gehouden dat er meerdere feiten in dezelfde straat zijn gepleegd. Toch bedraagt de NNI 0.58 wat significant kleiner is dan 1 en een aanduiding is dat de gegevens geclusterd zijn.

Cameron en Chainey (2000) stellen dat technieken die ruimtelijke autocorrelatie nagaan, zoals Moran's I, de aangewezen tests zijn voor clustering wanneer men enkel beschikt over geaggregeerde gegevens. Wanneer nabijgelegen punten meer gelijkenis vertonen met betrekking tot een variabele (in dit geval het aantal criminele feiten) dan verafgelegen punten wordt gesproken van een positieve ruimtelijke autocorrelatie. Een positieve ruimtelijke autocorrelatie wijst dus op het feit dat hoge waarden gepaard gaan met hoge waarden in nabijgelegen punten en dat lage waarden gepaard gaan met lage waarden in nabijgelegen punten of anders gezegd op ruimtelijke clustering. De waarden van de Moran's I variëren tussen -1 en +1 : hoge waarden worden verkregen wanneer nabijgelegen punten min of meer dezelfde waarden hebben. De Moran's I bevestigt enigszins dat de woninginbraken in het arrondissement Turnhout, geaggregeerd op het niveau van de straten, geclusterd zijn (Moran's $I=0.006, p<0,05$ ). De waarde van de Moran's I is echter zeer zwak positief : de kans dat er in de omgeving van een straat met inbraken, naast andere straten met inbraken (clustering), ook straten zonder inbraken zijn is door het zeer lage niveau van aggregatie immers groot. 


\section{Identificatie van hot spots}

11 Nadat is nagegaan of er globaal gezien sprake is van clustering bij de gegevens is het volgende doel de concentraties van feiten te identificeren. Zoals de Branting-hams in hun definitie van hot spots aanhaalden, kunnen de methodes om hot spots te identificeren worden ingedeeld in twee grote categorieën: de meer intuïtieve methodes waarbij de nadruk ligt op het bestuderen van kaarten die criminele feiten weergeven en de meer (statistische) analytische methodes. Achtereenvolgens zullen volgende methodes worden besproken :

- bestuderen van puntenkaarten of symboolkaarten

- bestuderen van choropleten

- clusteranalyse

- local indicators of spatial association (LISA)

- rasteranalyse

\section{Bestuderen van puntenkaarten of symboolkaarten}

Bij de puntenkaart wordt een punt geplaatst precies op de plaats waar het feit zich voordoet. Deze vorm van cartografische voorstelling is geschikt wanneer een exacte geocodering van de gebeurtenissen mogelijk is. Bij een symboolkaart wordt een symbool geplaatst op de precieze plaats van voorkomen van een bepaalde variabele of op een vooraf bepaalde gebiedsomschrijving (in dit geval vertegenwoordigt het middelpunt van een straat de gehele straat) en varieert het symbool in grootte in functie van de absolute waarde van een variabele (in dit geval het aantal feiten). Na het bestuderen van een puntenkaart of een symboolkaart kan men op een intuïtieve manier de hot spots aanduiden op de kaart. De voornaamste reden dat deze methode zeer vaak wordt gebruikt door strategisch analisten is de eenvoud qua uitvoering. Er zijn echter ernstige nadelen verbonden aan deze methode. Verschillende beoordelaars hebben vaak een andere mening over de plaats en de uitgestrektheid van de hot spots én over het aantal hot spots. Vooroordelen van de onderzoeker zijn niet uit te sluiten. Cognitief psychologisch onderzoek heeft meermaals het effect aangetoond van het kijken naar een patroon op een bevooroordeelde manier. Dit fenomeen wordt vaak geillustreerd met de volgende figuur. Deze figuur toont aan dat men vaak ziet wat men wil of verwacht te zien ook al is de realiteit anders (in dit geval is het niet evident dat de lezer opmerkt dat de lidwoorden «the » en "a » tweemaal voorkomen in de drie korte Engelstalige zinsneden in plaats van eenmaal). De hypothese dat inbraken vaak geconcentreerd zijn rond de belangrijkste invalswegen (autosnelwegen) kan onze beoordeling wat betreft de plaats van de hot spots beïnvloeden. 


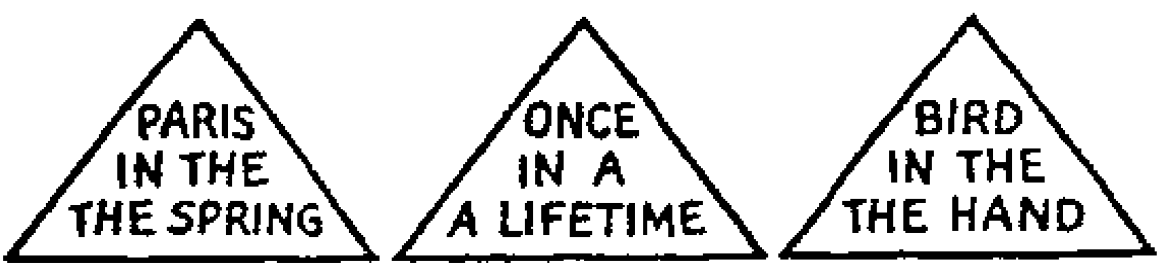

Daarnaast worden de intuïtieve criteria voor het bepalen van hot spots zelden geëxpliciteerd of gerapporteerd zodat de vergelijking van resultaten van onderzoeken over verschillende grondgebieden of tijdsintervallen zeer moeilijk is.

\section{Bestuderen van choropleten}

De choropleet is een kaart waarbij een vooraf bepaalde gebiedsindeling (vaak een administratieve eenheid) is ingekleurd in functie van een variabele die relatief van aard is. Net zoals bij een symboolkaart kan men na het bestuderen van de choropleet op een intuïtieve manier hot spots aanduiden. Men kan dan ook dezelfde voor- en nadelen aanhalen voor deze procedure. Een bijkomend nadeel is dat de visuele interpretatie van de kaart wordt bemoeilijkt door de verschillen qua vorm en grootte van de ingekleurde gebieden. De visuele aandacht zal vaak worden getrokken door de grotere gebieden hoewel het inbraak-risico in een kleiner gebied veel groter kan zijn. Bovendien bepalen de kleurgradaties die de onderzoeker aan de verschillende categorieën van de betrokken variabele toekent in belangrijke mate de cartografische voorstelling. Meer fundamenteel van aard is het nadeel dat administratieve gebiedsindelingen (fusiegemeenten, deelgemeenten, wijken, buurten) vaak straten gebruiken als grenzen van de deelgebieden. Daardoor worden reële hot spots vaak verdeeld over verschillende gebieden zoals is aangetoond in onderstaande figuur en zijn zij als dusdanig niet meer herkenbaar voor de onderzoeker. 
Figuur 2. Effect van gebiedsindeling o.b.v. straten voor reële hot spots.

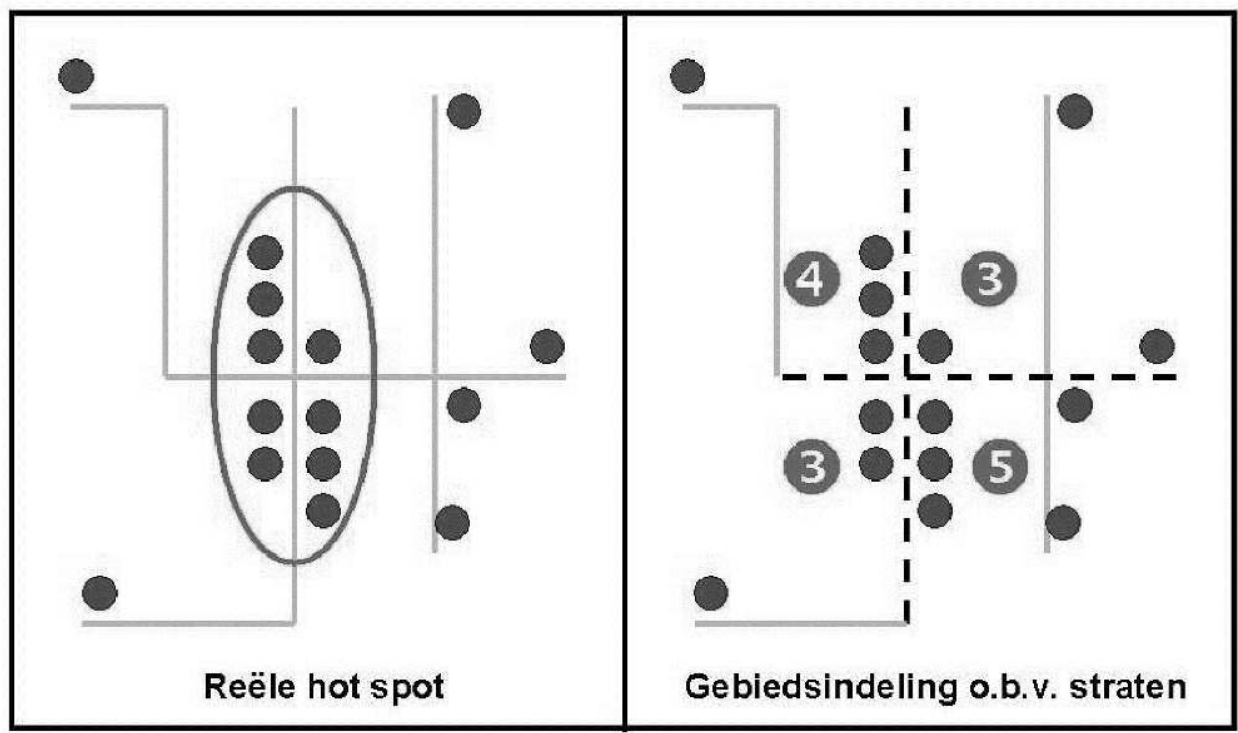

\section{Clusteranalyse}

Deze term duidt een groep van statistische technieken aan die feiten trachten te groeperen in relatief homogene clusters. Nearest neighbor hierarchical clustering groepeert feiten die ruimtelijk gezien dichter bij elkaar liggen dan volgens het toeval kan worden verwacht. Alleen feiten die voldoen aan dit criterium worden opgenomen in clusters. Deze clusters van de eerste orde worden opgenomen in clusters van een hogere orde wanneer zij op hun beurt ruimtelijk gezien dichter bij elkaar liggen dan volgens het toeval kan worden verwacht. Drie parameters zijn bepalend voor de resultaten van de analyse. Eerst en vooral is er het minimum aantal punten dat een cluster dient te omvatten. Deze parameter zorgt ervoor dat te kleine clusters buiten beschouwing worden gelaten. Wanneer de feiten volledig volgens het toeval zouden zijn gespreid over het grondgebied gaan een aantal feiten dicht genoeg bij elkaar liggen om opgenomen te worden in een cluster. De onderzoeker dient als tweede parameter de kans te bepalen dat feiten zouden worden opgenomen in clusters wanneer de gegevens volledig volgens het toeval zouden zijn gespreid over het grond-gebied. Deze parameter is vergelijkbaar met het bepalen van de (alfa-drempel-waarde bij de klassieke statistische tests. De nearest neighbor hierarchical clustering methode stelt de hot spots voor als ellipsen. De standaardafwijkingen van de X- en Y-coördinaten van de gegevens in de hot spots zijn bepalend voor de vorm en grootte van de ellipsen. De onderzoeker dient als laatste parameter te bepalen hoeveel standaardafwijkingen in rekening worden gebracht bij het bepalen van de grens van de hot spots.

Een tweede clustering methode is K-means partitioning clustering. Deze methode groepeert de gegevens in een aantal clusters (K) dat vooraf door de onderzoeker is bepaald. De procedure vindt de aangewezen middelpunten voor de K clusters en wijst elk feit toe aan één cluster op een manier dat de som van de afstanden tussen de gegevenspunten en de middelpunten van de clusters minimaal is. K-means partitioning 
clustering is nuttig wanneer het aantal concentraties reeds voor de analyse gekend is of door omstandigheden dient vast te liggen.

Een voordeel van nearest neighbor hierarchical clustering is dat nabijgelegen kleine clusters worden gegroepeerd tot clusters van een hogere orde. Dit verschil tussen primaire en secundaire clusters sluit ons inziens goed aan bij de informatiebehoeften van respectievelijk operationele, tactische en strategische aard. Ook het vooraf bepalen van het aantal concentraties bij K-means partitioning clustering sluit goed aan bij de operationele realiteit omdat men daardoor de mogelijkheden qua capaciteit en middelen kan laten bepalen welke concentraties prioritair dienen te worden aangepakt. Er zijn echter nadelen verbonden aan de clustering methodes. Ten eerste hebben de parameters die de onderzoeker voor de analyse bepaalt een grote invloed op het resultaat van de clustering methodes. Meer fundamenteel van aard is het nadeel dat criminaliteit zich niet in het keurslijf van ellipsen laat steken. In realiteit zal de vorm van een hot spot woninginbraken eerder het patroon van bebouwing (zoals lintbebouwing) volgen dan de vorm van een geometrische figuur (i.c. de ellips) aannemen.

\section{Local indicators of spatial association (LISA)}

Een local indicator of spatial association (LISA) geeft de mate weer waarin de waarde die een gebied beschrijft overeenkomt met de waarden van naburige gebieden. Een voorbeeld van een LISA is de local Moran statistic. Belangrijk bij de interpretatie is het besef dat de LISA een maat van gelijkheid is. Dit betekent dat een positieve waarde van een local Moran statistic niet noodzakelijk wijst op een concentratie van feiten. Een positieve waarde van de local Moran statistic voor een gebied kan erop wijzen dat het gebied een hoge waarde heeft en dat het wordt begrensd door gebieden met hoge waarden. Maar een positieve waarde van de local Moran statistic kan er ook op wijzen dat het gebied een lage waarde heeft en dat het wordt begrensd door gebieden met lage waarden. In termen van inbraakrisico kan een negatieve waarde van de local Moran statistic dus wijzen op een gebied dat zich positief onderscheidt van naburige gebieden (een laag inbraakrisico t.o.v. hoge inbraakrisico's) of op een gebied dat zich negatief onderscheidt van naburige gebieden (een hoog inbraakrisico t.o.v. lage inbraakrisico's). De cartografische voorstelling van de LISA laat dus toe om aangrenzende gebieden met ongeveer dezelfde waarden of sterk afwijkende waarden te onderscheiden. Om besluiten te formuleren in termen van hot spots is het noodzakelijk dat de cartografische voorstelling van de local Moran statistic wordt vergeleken met de kaart die de basisgegevens, het inbraakrisico van de buurten, voorstelt. Deze werkwijze kan dus op twee manieren helpen om hot spots te identificeren. Enerzijds helpt de LISA om homogene clusters (positieve waarden van de local Moran statistic) van gebieden met een hoog inbraakrisico te identificeren, anderzijds helpt het ons gebieden te identificeren die zich door een hoog inbraakrisico negatief onderscheiden van naburige gebieden (negatieve waarden van de local Moran statistic).

De moeilijkheden bij de interpretatie, veroorzaakt door de aard van de LISA en de interpreteerbaarheid van choropleten (zoals eerder reeds aangehaald), vormen het belangrijkste nadeel van het werken met een LISA. Het voordeel dat deze methode biedt is dat men een samenvatting krijgt van de basisgegevens, in ons geval de inbraakrisico's, zodat men bijna onmiddellijk homogene clusters van onveilige 
gebieden én gebieden met een abnormaal risico in vergelijking met naburige gebieden kan identificeren.

\section{Rasteranalyse}

Een geavanceerde methode om de spreiding van criminaliteit weer te geven is de rasteranalyse. Ratcliffe (2000) illustreert de methode van rasteranalyse aan de hand van volgende figuur. Een raster wordt over het hele bestudeerde grondgebied geplaatst (a). Daarna wordt op elk snijpunt van het raster een cirkel geplaatst en het aantal feiten binnen de oppervlakte van de cirkel geteld (b). Elk snijpunt van het raster krijgt op deze manier een waarde toegewezen die een aantal feiten weergeeft. Kernel density interpolation is een specifieke vorm van rasteranalyse. Bij kernel density interpolation worden de feiten gewogen in functie van hun afstand tot het snijpunt (c). Elk snijpunt van het raster krijgt op deze manier een waarde toegewezen die een gewogen aantal feiten weergeeft.

Figuur 3. De methode van rasteranalyse (naar Ratcliffe ${ }^{5}$ ).

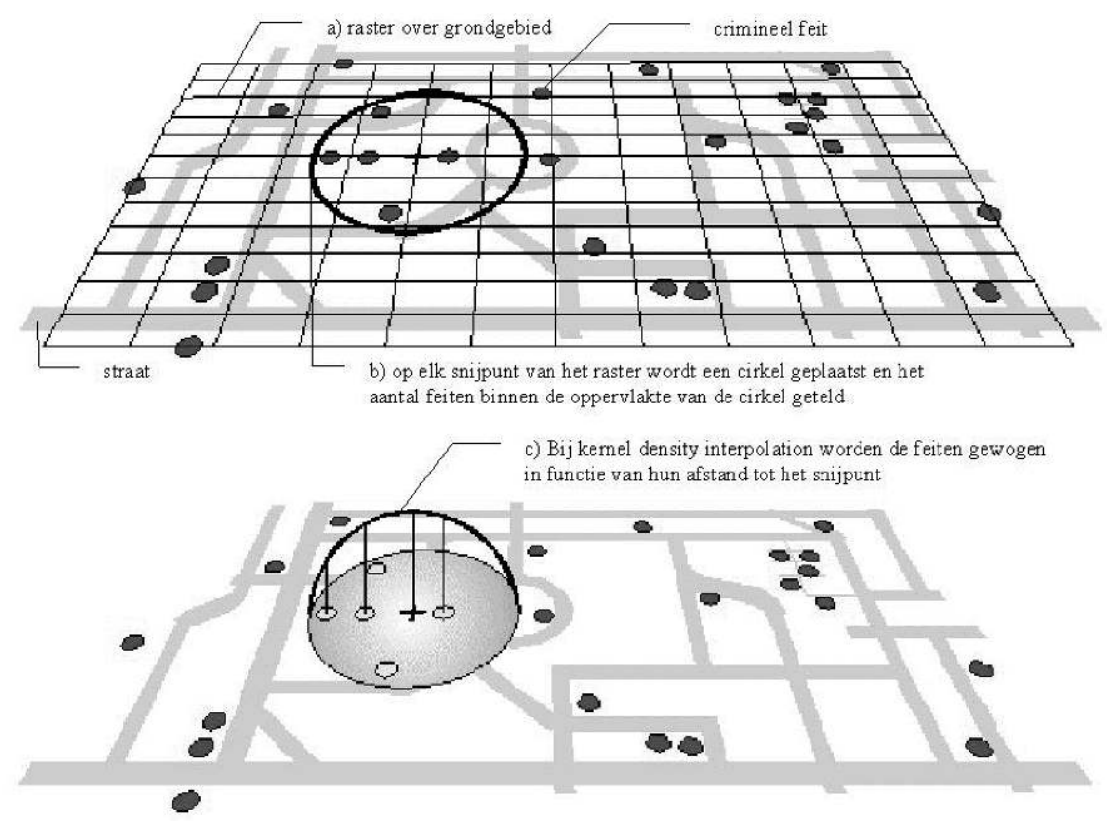

21 Twee parameters bepalen in belangrijke mate het resultaat van de analyse : de grootte van de rastercellen en de diameter van de cirkels. De grootte van de raster-cellen bepaalt of het resultaat een grof of vloeiend patroon is. De diameter van de cirkels bepaalt de mate van detail van de resultaten: een relatief kleine zoekradius ten opzichte van de grootte van het onderzoeksgebied zal meer lokale variaties tonen terwijl een grote diameter eerder algemene patronen laat verschijnen. De diameter van de cirkels kan absoluut worden bepaald door het aangeven van een afstandsmaat of op een adaptieve manier. Bij deze laatste werkwijze bepaalt de onderzoeker het aantal feiten dat een cirkel minimaal dient te omvatten en wordt de grootte van de cirkels hieraan aangepast. Daarnaast bepalen de kleurgradaties, die de onderzoeker toekent 
aan de verschillende categorieën van waarden verkregen door rasteranalyse, de cartografische voorstelling.

Het voordeel van rasteranalyse is dat hot spots nauwkeurig worden bepaald wat betreft plaats en intensiteit. De resultaten tonen de graduele afname van de concentraties wat ongetwijfeld een betere weergave van de realiteit is. Bovendien is de cartografische voorstelling van de resultaten van rasteranalyse visueel aantrekkelijk en esthetisch door de vloeiende kleurgradaties bij de patronen. De grote overeenkomst met weerkaarten en infraroodbeelden geeft de resultaten bovendien een wetenschappelijk aanzien. Hier schuilt ook het grote gevaar van de rasteranalyse. Gebruikers mogen nooit de validiteit, betrouwbaarheid en accuraatheid uit het oog verliezen waarmee de onderliggende gegevens, de criminele feiten, worden gemeten én gesynthetiseerd door de hot spot analyse. Steeds dient men zich te realiseren dat de parameters die men voor de analyse bepaalt en de kleurgradaties bij de weergave van het resultaat een grote invloed kunnen hebben op de visuele interpretatie van de resultaten.

\section{Samenvatting}

De voorgestelde methodes om hot spots te identificeren worden samengevat in volgende tabel.

Tabel 1. Overzicht van het aantal feiten geregistreerd per straat.

\begin{tabular}{|c|c|c|}
\hline $\begin{array}{l}\text { Aantal feiten per } \\
\text { straat }\end{array}$ & $\begin{array}{l}\text { Aantal } \\
\text { straten }\end{array}$ & $\begin{array}{l}\text { Percentage aantal straten } \\
\text { t.o.v. totaal aantal } \\
\text { stratenfeiten }\end{array}$ \\
\hline
\end{tabular}

\begin{tabular}{cccc}
\hline & & & \\
0 & 4989 & 77,72 & 0 \\
1 & 813 & 12,67 & 813 \\
2 & 297 & 4,63 & 594 \\
3 & 149 & 2,32 & 447 \\
4 & 84 & 1,31 & 336 \\
5 & 35 & 0,55 & 175 \\
6 & 18 & 0,28 & 108 \\
7 & 14 & 0,22 & 98 \\
8 & 9 & 0,14 & 72 \\
9 & 3 & 0,05 & 27 \\
10 & 3 & 0,05 & 30 \\
11 & 2 & 0,03 & 22 \\
13 & 2 & 0,03 & 26 \\
14 & 1 & 0,02 & 14 \\
\hline
\end{tabular}

\section{Het fenomeen woninginbraken in het arrondissement Turnhout}

Zoals hierboven reeds werd vermeld zijn de woninginbraken in het arrondissement Turnhout voor de hot spot analyse gegeocodeerd tot op het niveau van de straat waar de feiten zijn gepleegd. Dit betekent dat aan elk feit de X- en Y-coördinaten zijn toegekend van het centrale punt van de straat waar het feit heeft plaatsgevonden. De nauwkeurigheid van de analyse is met andere woorden beperkt tot op het niveau van 
de straten. Uiteraard is dit een ernstige tekortkoming op methodologisch vlak omdat het bij de statistische methodes die werken met puntgegevens vereist is dat deze exact bepaald zijn.

De lezer dient er zich echter van bewust te zijn dat het opzet van dit onderzoek nooit strikt wetenschappelijk of academisch is geweest. Integendeel, strategisch analisten bij politiediensten trachten de politiemensen op een zo concreet mogelijke manier te adviseren waar prioritair preventieve inspanningen moeten worden ingezet, waar (en wanneer) prioritair controlerende activiteiten dienen te worden ontplooid,... Met deze doelstellingen voor ogen menen wij dat het nauwkeurigheidsniveau (voorlopig) volstaat, als politiedienst moet er immers ook worden geroeid met de riemen die men heeft. We kunnen al wel vermelden dat de federale politie momenteel werkt aan een interpolatiemethode waarbij de geocodering van de feiten exacter zal verlopen op basis van straatsegmenten en huisnummers.

Aangezien de gegevens met betrekking tot de woninginbraken in het arrondissement Turnhout geaggregeerd zijn op het niveau van de straten zijn deze gegevens voorgesteld op een symboolkaart (Figuur 4). Na het bestuderen van deze symbool-kaart kan men op een intuïtieve manier de hot spots aanduiden (Figuur 5). Alle hot spots die door ons werden bepaald zijn gesitueerd in de omgeving van een autosnelweg. Geeft dit de realiteit weer of is dit resultaat eerder het gevolg van de algemeen aanvaarde hypothese dat inbraken vaak geconcentreerd zijn rond de belangrijkste invalswegen?

Figuur 4. Woninginbraken in het arrondissement Turnhout gedurende 2000.

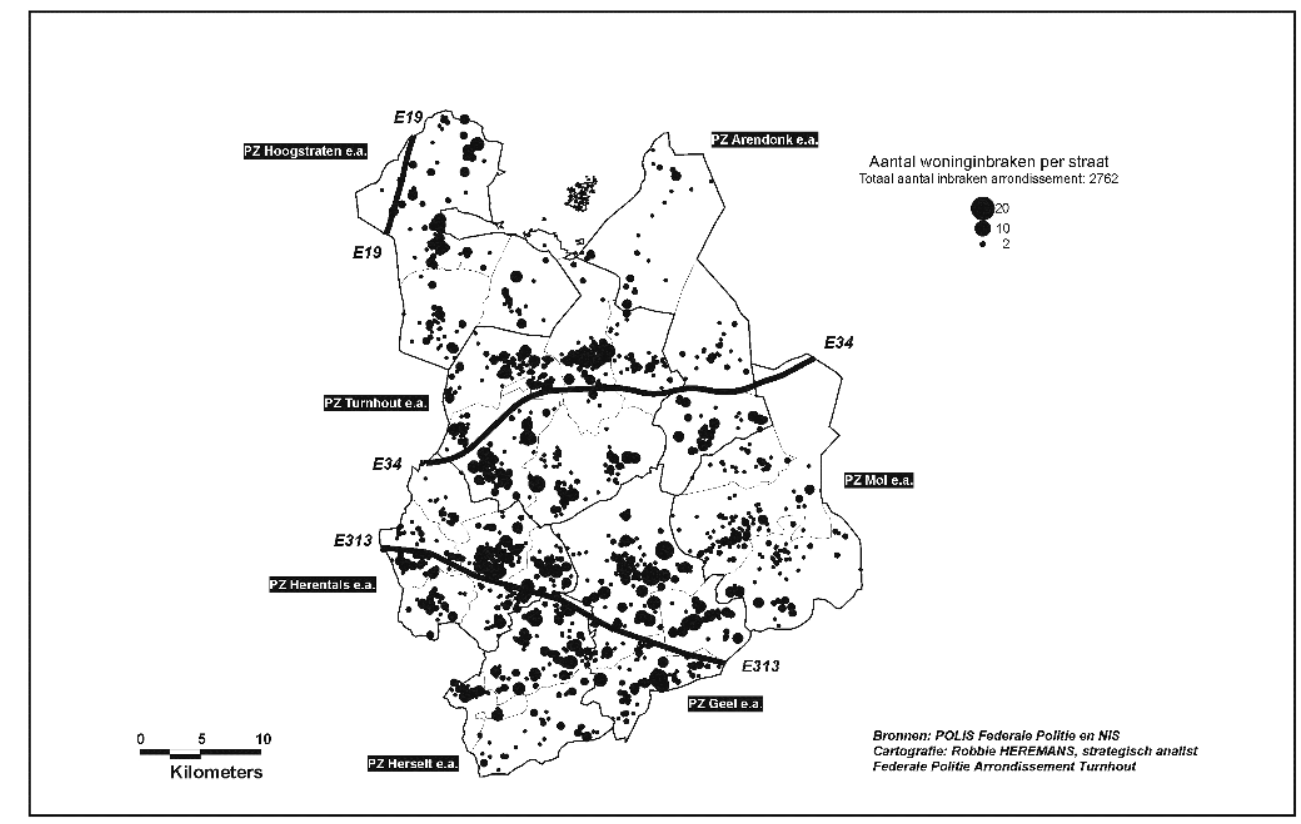


Figuur 5. Woninginbraken in het arrondissement Turnhout gedurende 2000. Symboolkaart met hot spots bepaald door analist.

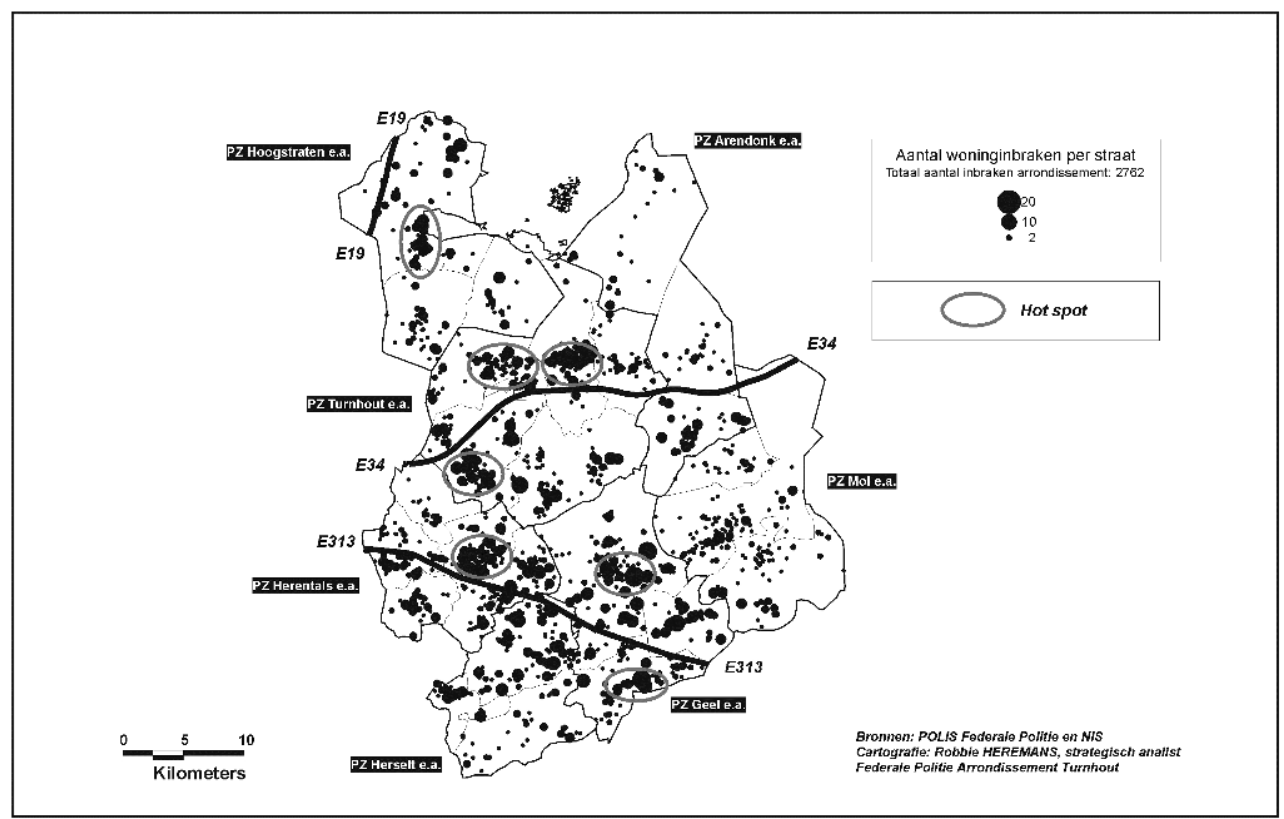

27 Wanneer het aantal inbraken in verhouding tot het aantal huishoudens (het « inbraakrisico », Figuur 6) wordt weergegeven op een choropleet kan men ook op een intuïtieve manier hot spots bepalen (Figuur 7). Ook hier zijn alle hot spots die door ons werden bepaald gesitueerd in de omgeving van een autosnelweg. Eveneens bepalend zijn de kleurgradaties die wij aan de verschillende categorieën van inbraakrisico hebben toegekend. Wij hebben gekozen voor 4 grijstinten waarvan de lichtste tint de buurten met een inbraakrisico dat lager is dan het arrondissementeel gemiddelde, namelijk. 18 inbraken per 1000 inwoners, weergeeft (307 buurten of $67 \%$ ). De donkerste grijstint geeft $5 \%$ van het totaal aantal buurten weer die het hoogste inbraakrisico kennen (28 van de 501 buurten). De twee midden-categorieën geven elk $16 \%$ van de buurten weer met een inbraakrisico tussen de lichtste en donkerste grijstint (respectievelijk buurten met een inbraakrisico van 18 tot 27 inbraken per 1000 huishoudens en buurten met een inbraakrisico van 27 tot 60 inbraken per 1000 huishoudens). Een andere klassenindeling had alleszins de cartografische voorstelling van de graad van woninginbraken gewijzigd en mogelijk een invloed gehad op onze interpretatie. 
Figuur 6. Woninginbraken in het arrondissement Turnhout gedurende 2000. Choropleet : aantal inbraken t.o.v. aantal huishoudens per buurt.

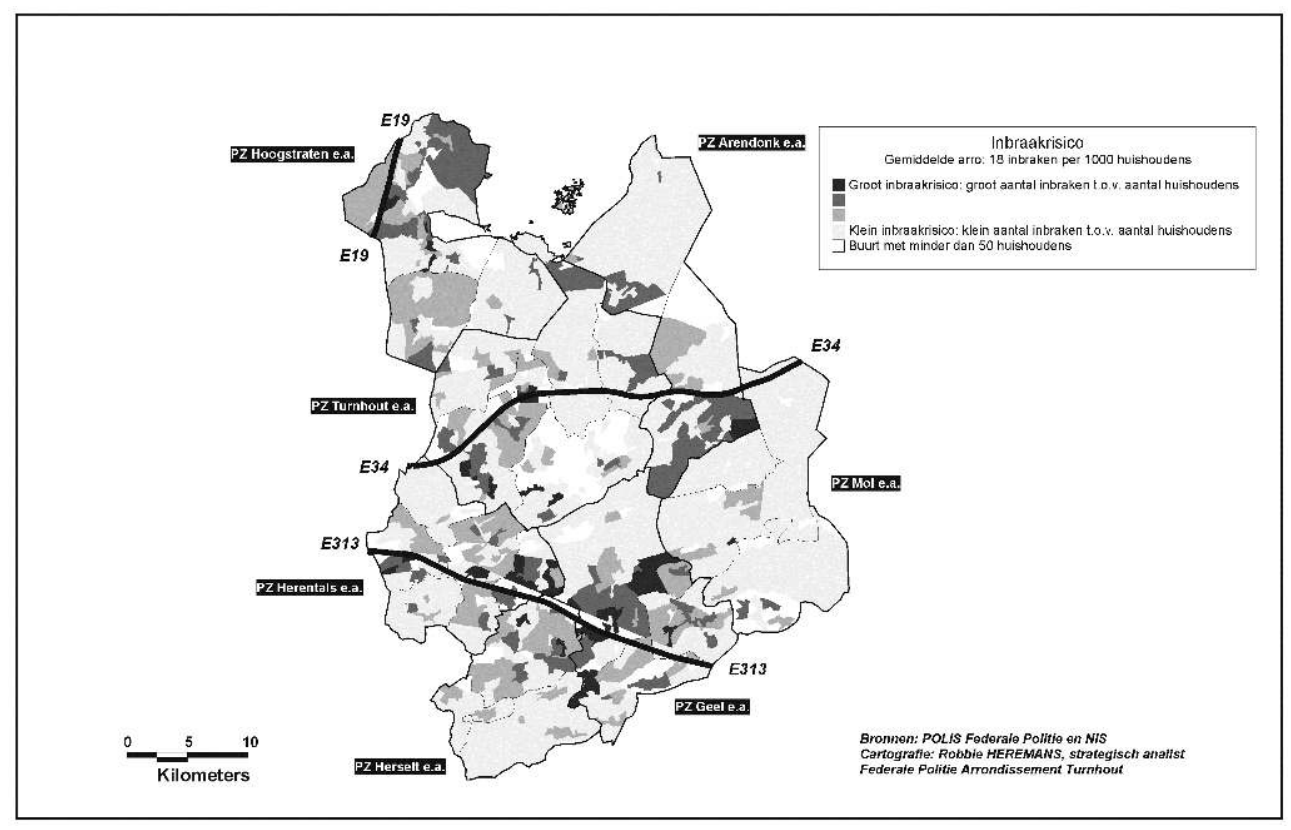

Figuur 7. Woninginbraken in het arrondissement Turnhout gedurende 2000. Choropleet : inbraakrisico per buurt met hot spots bepaald door analist.

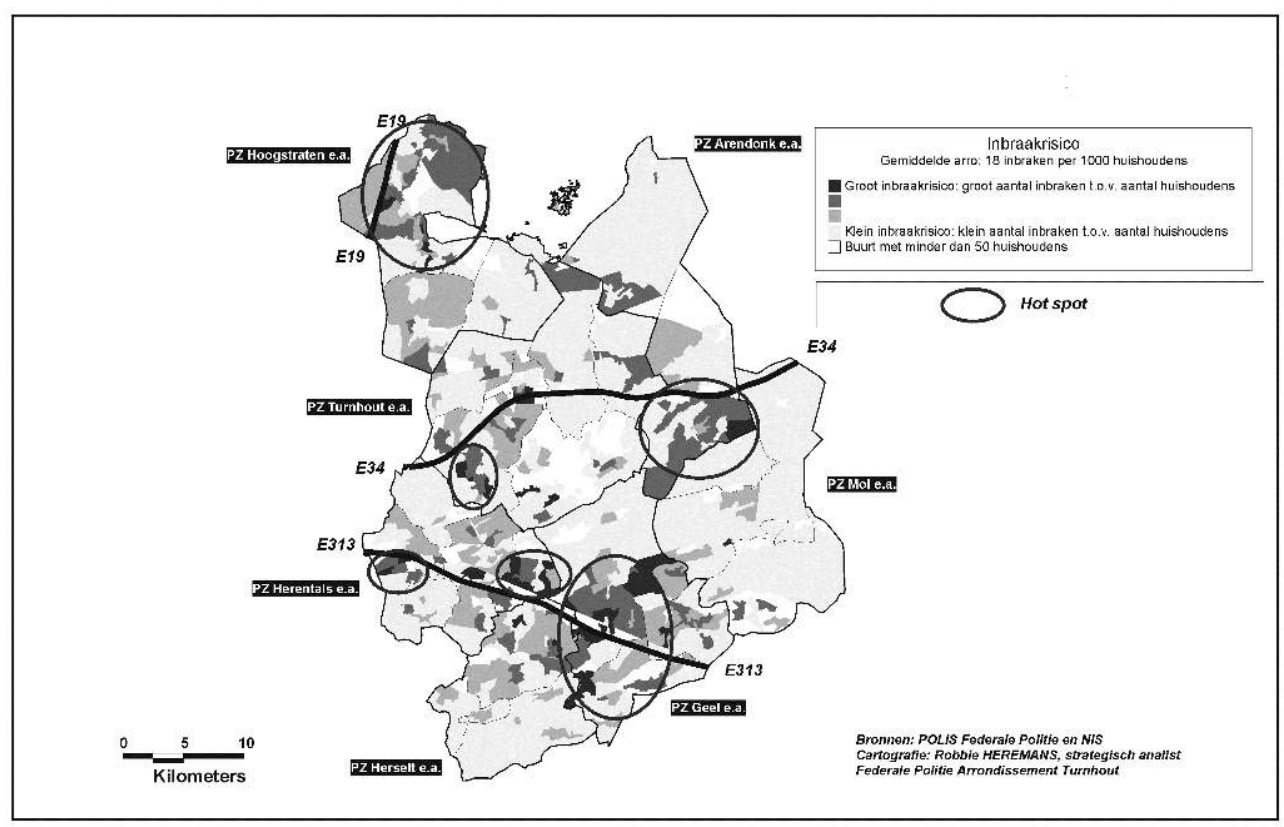

Dat deze klassenindeling niet cijfermatig is weergeven op de kaart, in tegenstelling tot wat men in wetenschappelijke en academische publicaties zou verwachten, is het gevolg van de doelgroep en het dagelijks gebruik van de voorgestelde kaarten. Deze kaarten zijn in de eerste plaats bestemd voor politiemensen die ze gebruiken voor het plannen van preventieve of controlerende acties.

29 Bij de identificatie van hot spots woninginbraken voor het arrondissement Turnhout met nearest neighbor hierarchical clustering werd bepaald dat een cluster diende te bestaan uit minimum 20 feiten en dat de kans op een toewijzing van een feit aan een 
cluster door het toeval $10 \%$ mocht bedragen (Figuur 8). De grenzen van de hot spots zijn zo bepaald dat de afstand van het middelpunt van een cluster tot de grens van de cluster gelijk is aan driemaal de standaardafwijkingen van de X- en Y-coördinaten van de gegevens in de cluster (concreet betekent dit dat ongeveer $99 \%$ van de feiten van een cluster is ingesloten door de grenzen van de cluster). We stellen vast dat een cluster van de tweede orde zich situeert in de omgeving van de autosnelweg E313. Dit kan er op wijzen dat er op strategisch vlak bijzondere aandacht moet uitgaan naar deze invalsweg bij het reduceren van de woningbraken in het arrondissement Turnhout.

Figuur 8. Woninginbraken in het arrondissement Turnhout gedurende 2000. Clusteranalyse : Nearest neighbor hierarchical clustering.

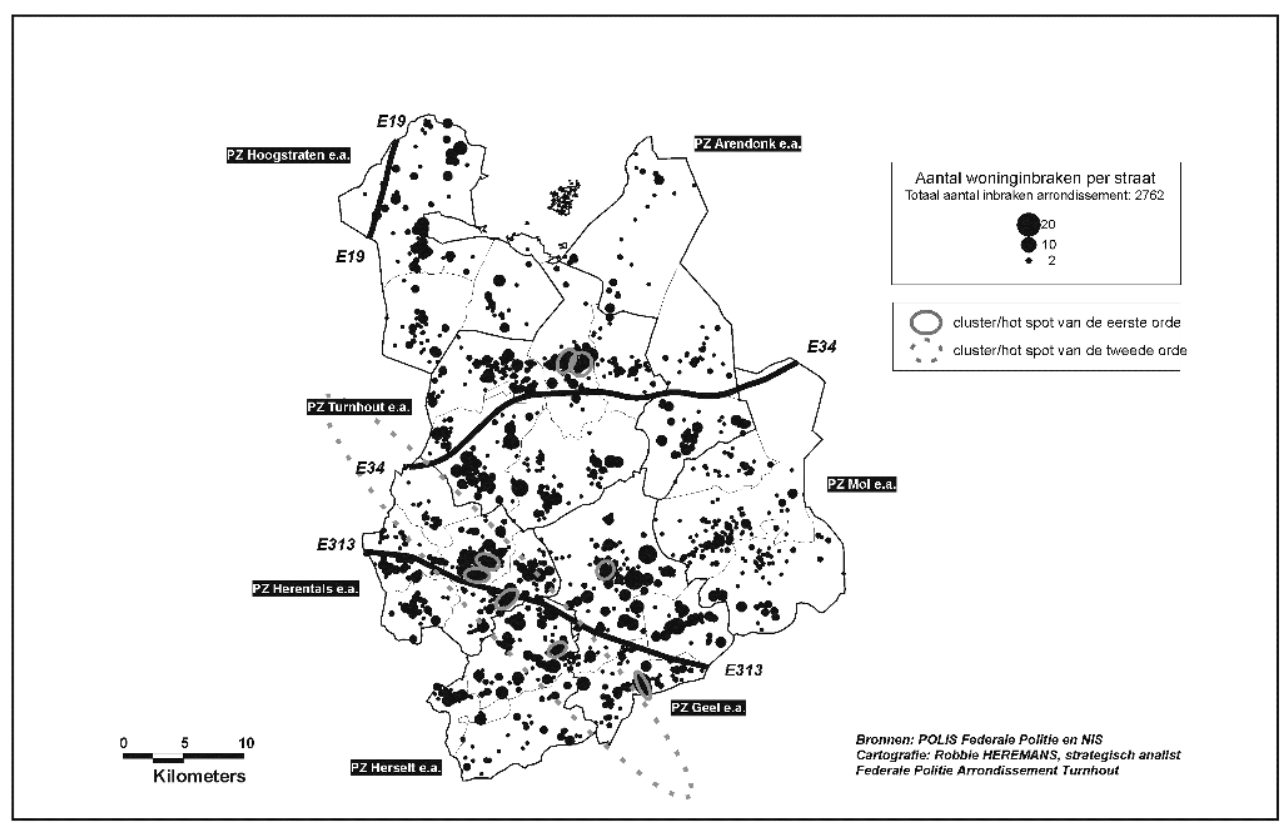

Bij de identificatie van de hot spots woninginbraken voor het arrondissement Turnhout met K-means partitioning clustering is bepaald dat het aantal concentraties 8 is, namelijk het aantal primaire clusters van de nearest neighbor hierarchical clustering methode (Figuur 9). We stellen vast dat de resultaten van de twee clusteringmethodes zeer verschillend zijn. Het uitgangspunt van de twee methodes is ook totaal verschillend. De nearest neighbor hierarchical clustering methode zoekt naar concentraties van feiten en de resultaten kunnen worden gebruikt voor het plannen van zeer gerichte preventieve of controlerende acties. De K-means partitioning clustering methode zoekt eigenlijk naar de plaatsen van een vooraf bepaald aantal middelpunten en is daarom geschikter om bijvoorbeeld de plaats van een vooraf bepaald aantal operationele uitvalspunten te bepalen of om het actieterrein van verschillende politieploegen te bepalen. 
Tabel 2. Samenvatting identificatiemethodes hot spots.

\begin{tabular}{|c|c|c|c|}
\hline METHODE & VOORDELEN & NADELEN & $\begin{array}{l}\text { BELANGRWKE } \\
\text { PARAMETERS }\end{array}$ \\
\hline $\begin{array}{l}\text { Bestuderen van puntenkaarten } \\
\text { of symboolkaarten }\end{array}$ & -eenvoud qua uitvoering & $\begin{array}{l}\text {-verschillen tussen beoordelaars } \\
\text {-invloed van vooroordelen }\end{array}$ & $\begin{array}{l}\text {-grotendeels impliciet bij } \\
\text { onderzoeker } \\
\text {-variatie symboolgrootte }\end{array}$ \\
\hline Bestuderen van choropleten & $\begin{array}{l}\text {-eenvoud qua uitvoering } \\
\text {-aandacht voor concentraties } \\
\text { van risico's i.p.v. concentraties } \\
\text { van feiten }\end{array}$ & $\begin{array}{l}\text {-idem puntenkaarten } \\
\text {-moeilijke visuele interpretatie } \\
\text {-straten als grenzen van deelgebieden }\end{array}$ & $\begin{array}{l}\text {-grotendeels impliciet bij } \\
\text { onderzoeker } \\
\text {-categorisering continue } \\
\text { waarden, kleurschakering }\end{array}$ \\
\hline $\begin{array}{l}\text { Nearest neighbor hierarchical } \\
\text { clustering }\end{array}$ & $\begin{array}{l}\text {-identificatie clusters hogere } \\
\text { orde }\end{array}$ & $\begin{array}{l}\text {-grote invloed van parameters op } \\
\text { resultaat } \\
\text {-keurslij van ellipsen }\end{array}$ & $\begin{array}{l}\text {-minimum aantal punten } \\
\text {-kans voor clustering door } \\
\text { toeval } \\
\text {-aantal standaardafwijkingen } \mathrm{X} \text { - } \\
\text { en } \mathrm{Y} \text {-coördinaten }\end{array}$ \\
\hline $\begin{array}{l}\text { K-means } \\
\text { partitioning }\end{array}$ & $\begin{array}{l}\text {-vooraf aantal clusters bepalen } \\
\text { sluit aan bij operationele } \\
\text { realiteit (capaciteit en } \\
\text { middelen) }\end{array}$ & $\begin{array}{l}\text {-grote invloed van parameters op } \\
\text { resultaat } \\
\text {-keursliff van ellipsen }\end{array}$ & -aantal clusters \\
\hline $\begin{array}{l}\text { Local indicators } \\
\text { of spatial asso- } \\
\text { ciation (LISA) }\end{array}$ & $\begin{array}{l}\text {-geeft samenvatting } \\
\text { geaggregeerde gegevens } \\
\text {-mogelijkheid om concentraties } \\
\text { van risico's én gebieden die } \\
\text { zich door een hoog risico } \\
\text { onderscheiden van naburige } \\
\text { gebieden te identificeren }\end{array}$ & -moeilijke interpretatie & $\begin{array}{l}\text {-matrix van gewichten op basis } \\
\text { van afstand (continu) of al dan } \\
\text { niet aangrenzend zijn (discreet) }\end{array}$ \\
\hline Rasteranalyse & $\begin{array}{l}\text {-nauwkeurigheid weergave } \\
\text { graduele afname -visuele } \\
\text { aantrekkelijkheid }\end{array}$ & $\begin{array}{l}\text { grote invloed van parameters op } \\
\text { resultaat }\end{array}$ & $\begin{array}{l}\text {-grootte rastercellen } \\
\text {-zoekradius (diameter cirkels) in } \\
\text { verhouding tot omvang } \\
\text { onderzoeksgebied }\end{array}$ \\
\hline
\end{tabular}

Figuur 9. Woninginbraken in het arrondissement Turnhout gedurende 2000. Clusteranalyse : KMeans Partitioning Clustering (aantal gevraagde clusters $=8$ ).

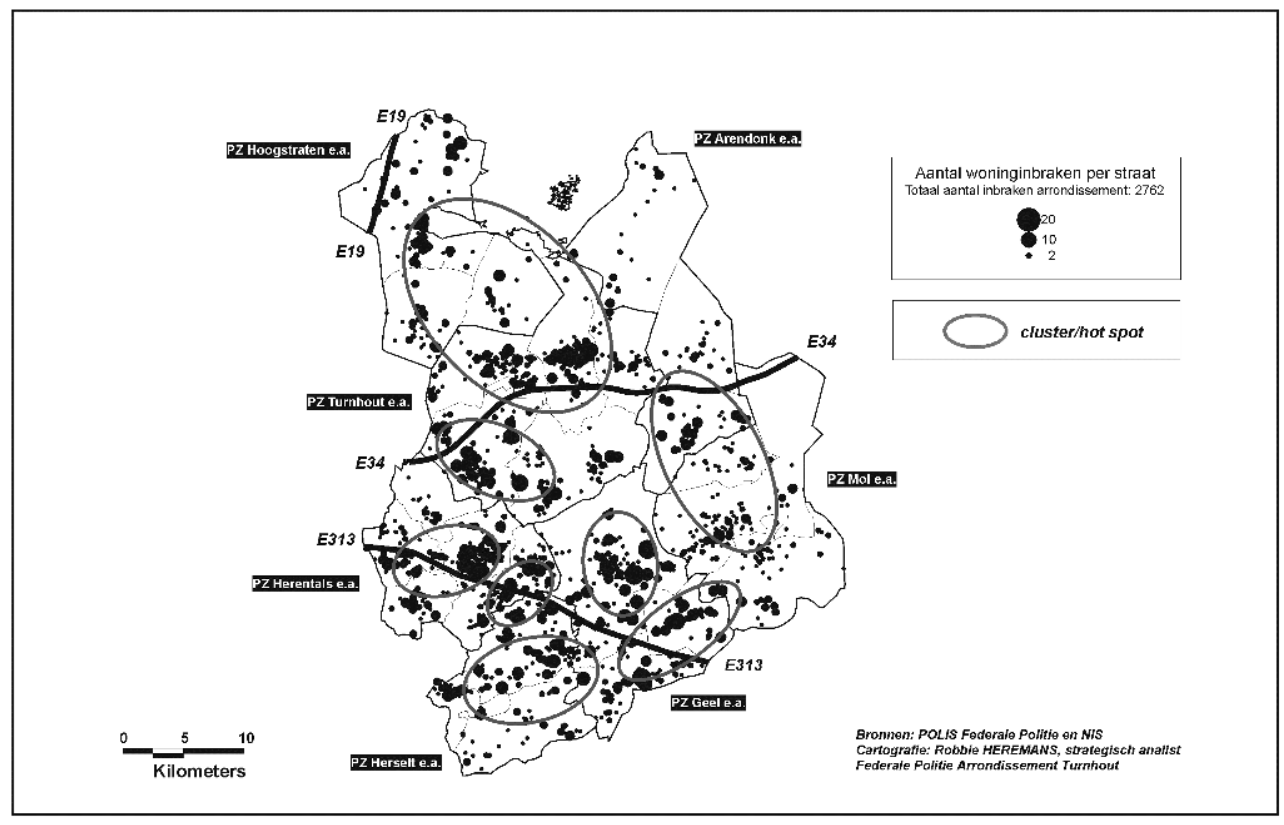

31 Een local indicator of spatial association (LISA) zoals de local Moran statistic laat ons toe om de mate van gelijkheid tussen naburige buurten qua inbraakrisico na te gaan (Figuur 10). Om besluiten te formuleren in termen van hot spots is het noodzakelijk dat de cartografische voor-stelling van de local Moran statistic wordt vergeleken met de kaart die de inbraak-risico's voorstelt (Figuur 6). We stellen vast dat er in het zuiden 
van het arrondissement Turnhout, aan de autosnelweg E313, een homogeen gebied is van buurten met een hoog inbraakrisico. Dit gebied zou met andere woorden een homogeen onveilig gebied kunnen worden genoemd. In het noorden van het arrondissement Turnhout zou men veeleer kunnen spreken van een homogeen veilig gebied waarin zich echter een aantal buurten bevinden met een abnormaal hoog inbraakrisico in vergelijking met hun omgeving. Deze vaststellingen zijn belangrijk op het beleidsmatige, strategische vlak aangezien zij aantonen dat het noordelijk en zuidelijk gedeelte van het arrondissement vragen om een andere politionele aanpak.

Figuur 10. Woninginbraken in het arrondissement Turnhout gedurende 2000. Local Moran Statistics : Ruimtelijke verbanden wat betreft de inbraakrisico's van buurten.

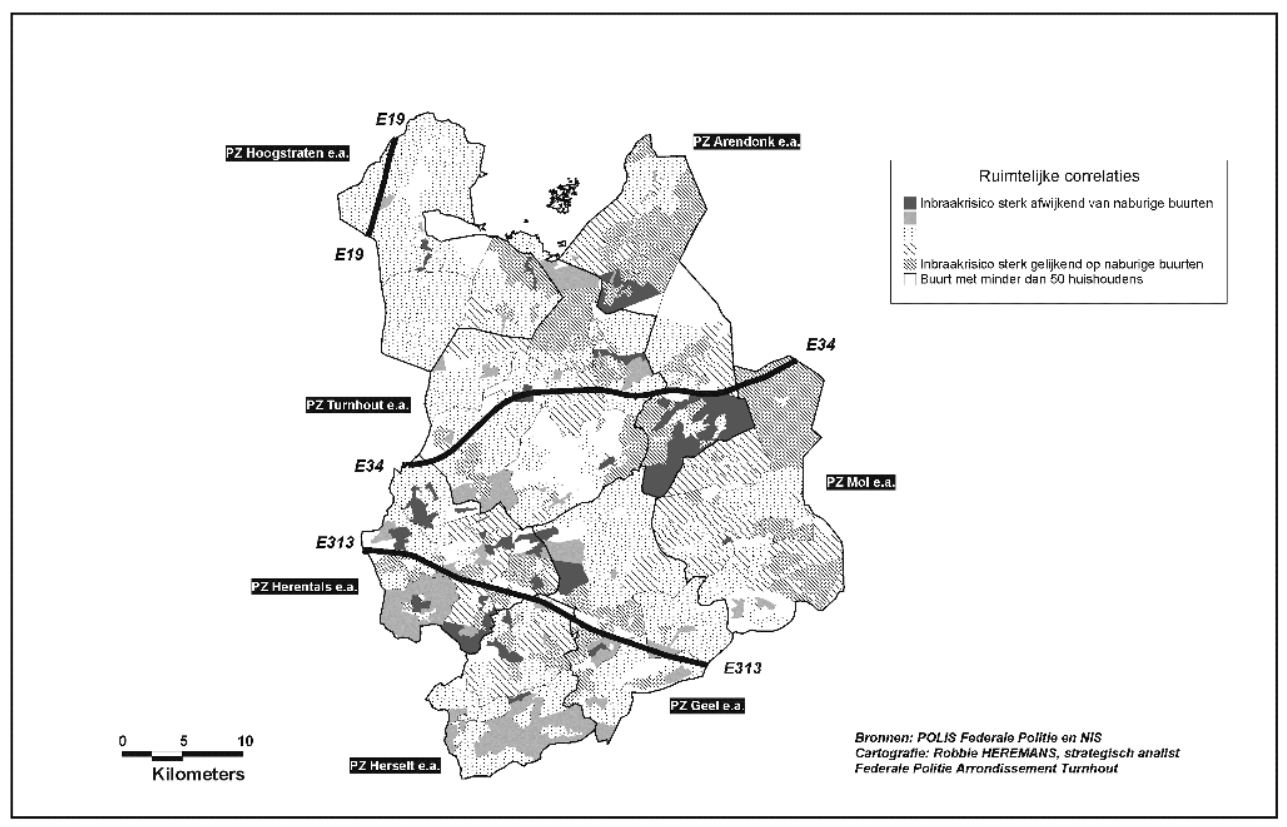

Bij de identificatie van hot spots woninginbraken voor het arrondissement Turnhout met rasteranalyse (kernel density interpolation) werd bepaald dat de cirkels minimaal 50 feiten omvatten. Op het grondgebied van het arrondissement Turnhout werd een raster geplaatst dat 100 kolommen breed en 132 rijen hoog is. Dit betekent dat de oppervlakte van elke rastercel $0,17 \mathrm{~km} 2$ bedraagt. De resultaten tonen aan dat de woninginbraken vooral in het zuidelijk gedeelte van het arrondissement geconcentreerd zijn (Figuur 11). Deze methode maakt eveneens de graduele afname van de kernen van de hot spots tot hun grenzen aanschouwbaar. 
Figuur 11. Woninginbraken in het arrondissement Turnhout gedurende 2000. Kernel Density Interpolation : ruimtelijke concentraties bepaald door rasteranalyse.

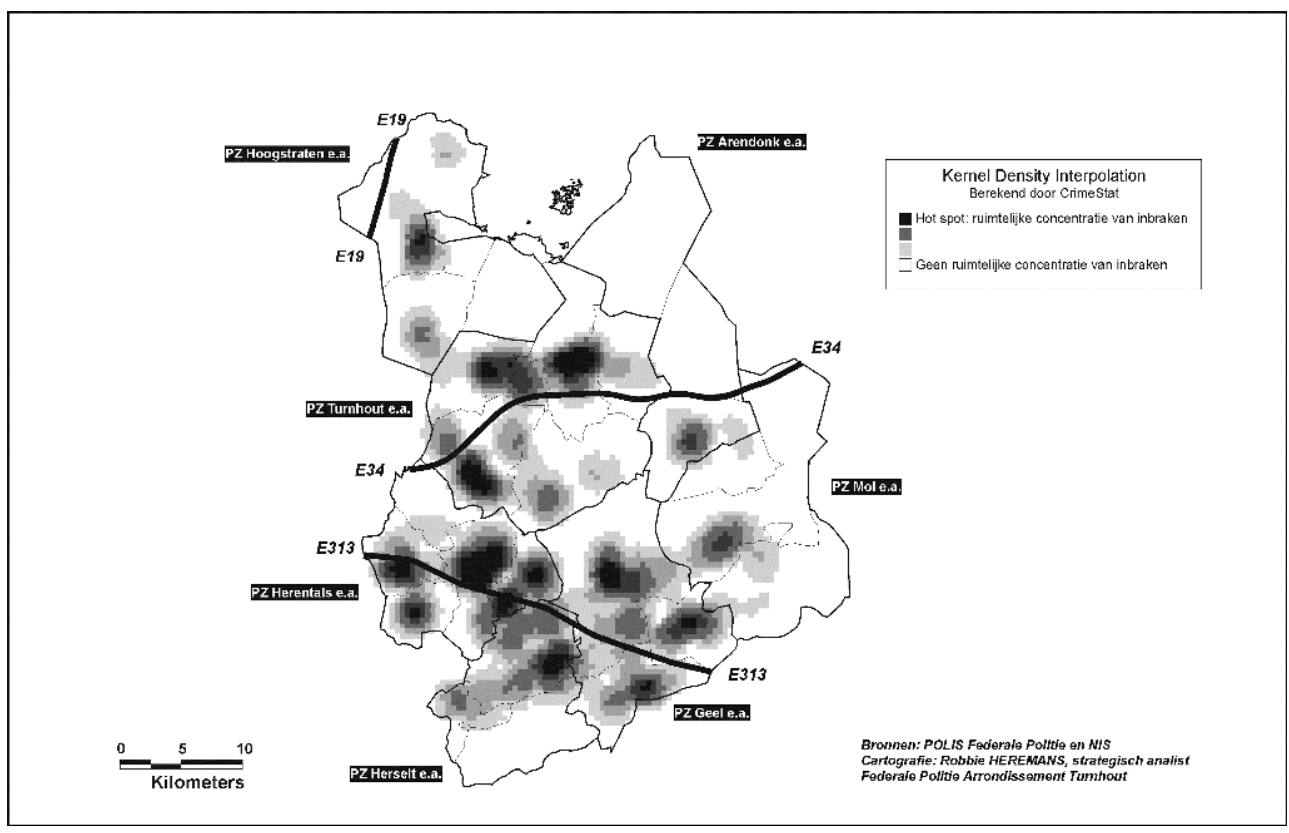

\section{Verklaring van hot spots}

Een hot spot analyse eindigt niet met de identificatie van de hot spots. Er moet ook worden gezocht naar een verklaring van de concentraties van criminele feiten zodat de oorzakelijke factoren kunnen worden aangepakt.

Brantingham en Brantingham (1999) stellen dat men bepaalde criminele hot spots in Noord-Amerikaanse grootsteden op een eenvoudige manier kan verklaren. Plaatsen waar potentiële doelen zijn geconcentreerd in de nabijheid van plaatsen waar een groot aantal potentiële daders verblijven zijn vaak veroordeeld tot een bestaan als hot spot. Verblijfplaatsen van daders zijn door de markt van onroerende goederen en het ruimtelijk beleid van de overheid vaak geconcentreerd in de verloederde buurten rond de winkel- en zakencentra van steden. Op basis van de plaatsen waar wagens worden teruggevonden die zijn gestolen bij woninginbraken, kan men afleiden dat dadergroepen die verantwoordelijk zijn voor een groot deel van de inbraken in de Kempen in bepaalde wijken van Antwerpen verblijven. Het ruimtelijk beleid van de overheid en de dagelijkse activiteiten van slachtoffers bepalen vaak de plaatsen waar potentiële doelen geconcentreerd zijn. Met betrekking tot de woninginbraken bepaalt het ruimtelijk beleid bijvoorbeeld waar concentraties van woningen worden ingeplant en welk type van bebouwing in wijken is toegelaten. Het dagelijkse ritme van pendelaars (overdag buitenhuis werken en 's nachts slapen) maakt dat wijken waar veel pendelaars verblijven een bepaalde aantrekkingskracht uitstralen naar potentiële daders. De Brantinghams stellen dat hun eenvoudig verklaringsmodel voor hot spots eigenlijk verschillende criminologische theorieën bundelt ("ecological theories", " housing competition theories ", « land use theories " en " routine activity theories ») tot één geïntegreerd model. Dus, hoewel het model van de Brantinghams bedoeld is om criminele hot spots in Noord-Amerikaanse grootsteden te verklaren, kan het ons een 
referentiekader aanreiken voor het verklaren van hot spots van woninginbraken in het arrondissement Turnhout.

In sommige gevallen zal het eenvoudige model de geïdentificeerde hot spots onvoldoende verklaren. De Brantinghams stellen in zulke gevallen voor om rekening te houden met een aantal achtergrondkenmerken van de omgeving zoals de gewone verplaatsingspatronen, specifieke plaatsen die criminaliteit doen ontstaan of aantrekken en het etiket dat wijken of regio's van criminelen krijgen. De bereikbaarheid van een gebied door grote invalswegen (bijvoorbeeld door de nabijheid van afritten van autosnelwegen) of openbaar vervoer (bijvoorbeeld door de aanwezigheid van treinstations en bushaltes) verklaart in belangrijke mate het risico voor woninginbraken. Specifieke plaatsen die criminaliteit doen ontstaan ( crime generators ») zijn plaatsen waarnaar een groot aantal mensen komen omwille van één of andere reden die niet gerelateerd is met criminaliteit. Voorbeelden hiervan zijn scholen, discotheken, winkelstraten, sport- of winkelcentra. Potentiële daders van criminele feiten begeven zich net als iedereen naar die specifieke plaatsen zonder de intentie om feiten te plegen, maar zullen zich ter plaatse bewust worden van de mogelijkheden van de omgeving voor criminele daden. Plaatsen die criminaliteit aantrekken (« crime attractors ») zijn buurten of regio's waarnaar gemotiveerde daders zich begeven omwille van de specifieke mogelijkheden die de plaatsen bieden op crimineel vlak. Het uitverkoren terrein voor inbrekers bijvoorbeeld zijn villawijken (aanzienlijke buit, losstaande woningen) die gelegen zijn aan afritten van autosnelwegen. De aantrekkingskracht van een specifieke plaats voor criminelen wordt in belangrijke mate bepaald door het criminele etiket van het gebied. Het criminele etiket is een beeld dat criminelen hebben van een gebied met betrekking tot de mogelijkheden voor het plegen van feiten. Het etiket krijgt vorm door persoonlijke ervaringen van criminelen, ervaringen van andere daders en door de algemene berichtgeving in de media. Naast de achtergrondkenmerken dient men volgens de Brantinghams ook rekening te houden met de zichtbare kenmerken van de omgeving voor het verklaren van hot spots. Met betrekking tot de hot spots van woninginbraken kan de mate dat huizen zichtbaar zijn door straatverlichting of omheiningen een invloed hebben.

Clarke (1997) bundelt verschillende omgevingsfactoren die de gelegenheid voor het plegen van criminele feiten bepalen tot één model. De gelegenheid voor het plegen van criminele feiten bestaat uit drie componenten: slachtoffers, doelen en faciliterende factoren. Met deze laatste component bedoelt de auteur de aanwezigheid van werktuigen (zoals ladders of zaken voor een raam stuk te slaan bij woninginbraken) en middelen die gevoelens van angst bij daders onderdrukken (zoals alcohol of drugs). De fysieke omgeving (toegangswegen, aard bebouwing) en de dagelijkse activiteiten van de bevolking beïnvloeden de aantrekkingskracht van potentiële doelen. De dagelijkse activiteiten en levensstijl van personen bepalen in welke mate er (sociale) controle is over de mogelijke doelen en hebben ook een invloed op het aan- of afwezig zijn van potentiële slachtoffers. De fysieke omgeving en de levensstijl van mensen zijn op hun beurt bepaald door de ruime sociaal-economisch maatschappelijke realiteit. Clarke besluit dat de mate waarin potentiële daders het risico, de inspanning en de beloning van hun daden inschatten in belangrijke mate bepaalt waar en wanneer zij de criminele feiten plegen. 
Het model van Clarke kan worden gekoppeld aan het model van Martens (1990, in Bottoms en Wiles, 1992). Dit laatste model stelt expliciet dat de verschillende omgevingsinvloeden op drie verschillende schaalniveaus kunnen inwerken op het individu en de criminaliteit: op het macro-niveau (de ruime sociaal-economisch maatschappelijke realiteit bij Clarke), op het mesoniveau (de fysieke omgeving en de levensstijl van mensen bij Clarke) en op het microniveau (gelegenheid voor het plegen van criminele feiten bij Clarke). Ook het model van Martens benadrukt dus dat het de wisselwerking tussen het individu en de omgeving en vooral ook het aanbod aan gelegenheden en de sociale controle zijn, die de aanwezigheid van criminaliteit kunnen verklaren.

Figuur 12. Omgevingsfactoren van criminaliteit.

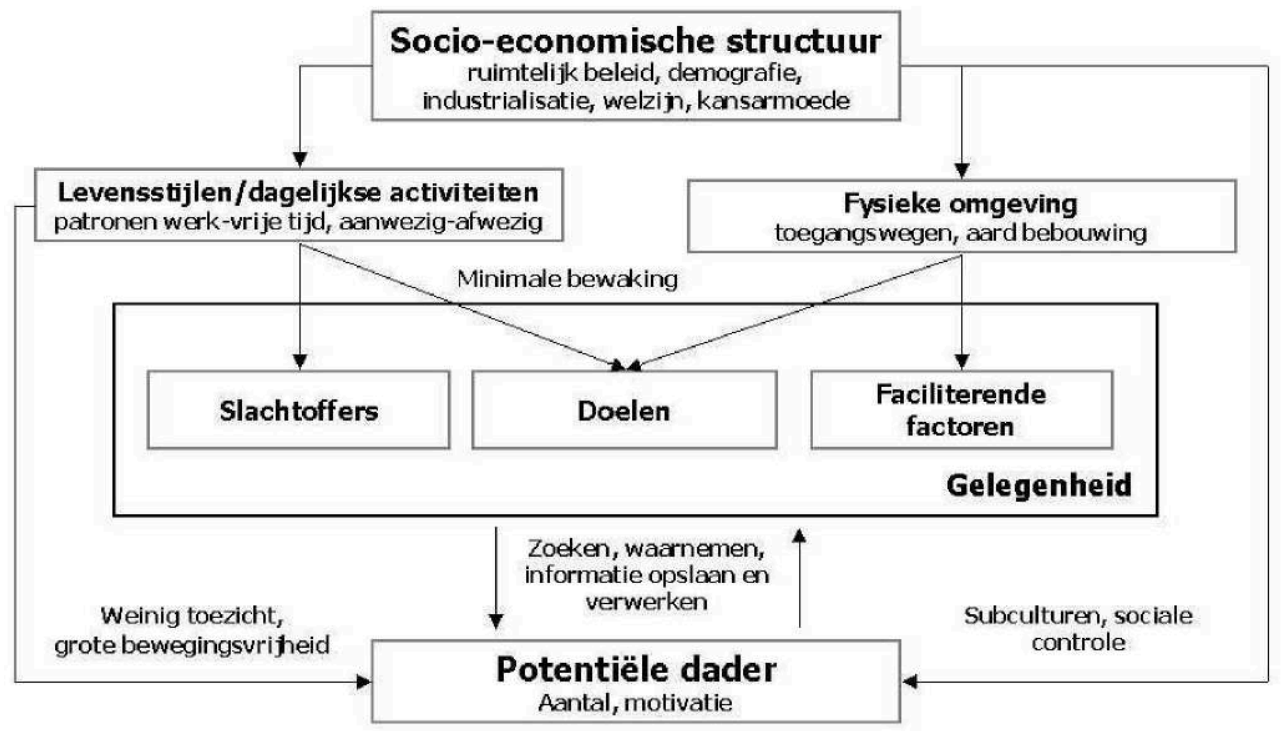

\section{Toekomstperspectieven}

We haalden reeds aan dat ruimtelijke concentraties van criminele feiten slechts gedurende de laatste decennia de nodige aandacht krijgen. Dit betekent dat het instrumentarium voor hot spot analyse nog volop wordt uitgebouwd. De technieken die onderzoekers nu ontwikkelen zullen nadien in softwarepaketten voor criminologen, geografen en strategisch analisten bij politiediensten worden geïnte-greerd en dit zal de analyse van hot spots nieuwe impulsen geven. Levine (1999) haalt bijvoorbeeld het werk aan van diverse auteurs zoals Bowman en Azzalini (1997) en Kelsall en Diggle (1995) in verband met significantietoetsen voor kernel density interpolation waarden. Getis en Ord (1992 en 1995) ontwikkelden reeds een methode die toelaat een local indicator of spatial association (LISA) statistisch te valideren. In de toekomst zal het dus mogelijk zijn om naast de exploratieve onderzoeken ook conclusieve hot spot analyses te maken en zal men met andere woorden kunnen nagaan in welke mate een hot spot aan het toeval te wijten is dan wel een niet toevallig - men zegt statistisch significant fenomeen betreft.

Daarnaast wordt de selectie van parameters bij de (statistische) analytische methodes onderzocht. Dalton (2000) heeft bijvoorbeeld een werkwijze ontwikkeld die toelaat de 
parameters voor kernel density interpolation op een optimale manier te selecteren. Zijn methode laat ook toe om een hot spot in detail te bestuderen voor het bepalen van de «hottest spot». Het hoeft geen betoog dat een selectie van parameters op een methodologische manier voordelen heeft ten opzichte van de huidige manier waarbij de intuïtie en ervaring van de onderzoeker de kwaliteit van de parameters bepaalt.

Naast de ontwikkelingen op het methodologisch vlak is het ook uitkijken naar de publikatie « Understanding hot spots » door het Crime Mapping Research Center die zal verschijnen in het najaar van 2001.

\section{Besluit}

41 Het doel van hot spot analyse is plaatsen met een bijzondere, hoge concentratie van criminele feiten te onderscheiden van andere gebieden. Het gebrek aan capaciteit en middelen bij de politiediensten maakt hot spot analyse aantrekkelijk omdat het toelaat de beperkte middelen op een gerichte manier in te zetten. De kloof tussen het theoretisch concept « hot spot » en de praktijk is dus klein. De (statistische) analytische methodes zorgen er ook voor dat de resultaten van een hot spot analyse slechts in beperkte mate worden beïnvloed door de vooroordelen van de analisten en politiemensen. Bovendien is hot spot analyse per definitie een visuele aangelegenheid en is het belang van een goede visuele voorstelling van analyseresultaten gekend. Samengevat kan hot spot analyse dus worden omschreven als een wetenschappelijke methode met resultaten die door het visuele karakter steeds aanspreken en onmiddellijk in de praktijk kunnen worden gebruikt.

Er zijn echter ook een aantal theoretische en methodologische nadelen verbonden aan hot spot analyse. Ten eerste heeft de onderzoeker ook bij de zogenaamde wetenschappelijke methodes nog een grote invloed op het resultaat van de analyse doordat men één of meerdere parameters dient te bepalen. Levine (1999) besluit daarom dat : "...isolating clusters (or «hot spots ») can be as much an art as it is a science. » Bovendien wordt een hot spot meestal gedefinieerd als een plaats met een bijzondere hoge concentratie van criminele feiten. Door deze omschrijving is de aandacht van onderzoekers zowel op conceptueel als methodologisch vlak bijna exclusief uitgegaan naar de analyse van plaatsen met een hoog aantal feiten in absolute zin. Dit heeft tot gevolg dat de technieken voor de analyse van plaatsen met een hoog risico, relatief bekeken ten opzichte van een andere variabele, zeer weinig aandacht hebben gekregen. Tenslotte zijn de geocodering van feiten en de identificatie van de hot spots vaak zeer tijdrovende activiteiten. Tijdsgebrek is waarschijnlijk de belangrijkste reden dat een zeer belangrijk onderdeel van een hot spot analyse namelijk het verklaren van de hot spot, het identificeren van de oorzaken zodat oplossende maatregelen kunnen worden voorgesteld, vaak wordt beperkt tot een minimum. Daarom willen wij er als algemeen besluit op wijzen dat de statistische methodes enkel toelaten om "schijnbare" hot spots te identificeren. De identificatie van een "reële" hot spot is er pas wanneer de bijzondere hoge concentratie van criminele feiten ook op voldoende wijze is verklaard. Het verklaren en voorspellen van hot spots is echter niet eenvoudig zoals Ken Pease ${ }^{6}$ (UK criminology professor) treffend omschrijft: "Predicting crime hot spots is rather like mapping bubbles in a pan of boiling water in an attempt to discern the shape of the heating element $»$. 


\section{BIBLIOGRAPHIE}

BOTTOMS A. and WILES P. (1992), « Explanations of crime and place », in EVANS D.J., FYFE N.R. and HERBERT D.T. (eds.), Crime, policing and place: essays in environmental criminology, Routledge, New York.

BOWMAN A.W. and AZZALINI A. (1997), Applied Smoothing Techniques for Data Analysis: The Kernel Approach with S-Plus Illustrations, Oxford Science Publications, Oxford University Press, Oxford, England.

BRANTINGHAM P.L. and BRANTINGHAM P.J. (1999), « A Theoretical Model of Crime Hot Spot Generation ", Studies on Crime and Crime Prevention, 8, pp. 7-26.

CLARKE R.V. (Ed.) (1997), Situational Crime Prevention: Successful Case Studies, Harrow \& Heston, Albany, NY.

CAMERON J. and CHAINEY S. (2000), « Hot Spot Methods », in Proceedings of the Fourth Annual International Crime Mapping Research Conference, Crime Mapping Research Center, Washington, DC.

DALTON J. (2000), « Parameter Selection for Spatial Density Estimation », in Proceedings of the Fourth Annual International Crime Mapping Research Conference, Crime Mapping Research Center, Washington, DC.

GETIS A. and ORD J.K. (1992), « The analysis of spatial association by distance statistics ", Geographical Analysis, 24, pp. 189-206.

HARRIES K. (1999), Mapping Crime : Principle and Practice, Crime Mapping Research Center, Washington, DC.

HEUER R.J. Jr. (1999), Psychology of Intelligence Analysis, Center for the Study of Intelligence, Washington, DC.

KELSALL J.E. and DIGGLE P.J. (1995), « Non-parametric estimation of spatial variation in relative risk », Statistical Medicine, 14, pp. 2335-2342.

LEVINE N. (1999), CrimeStat : A Spatial Statistics Program for the Analysis of Crime Incident locations, The National Institute of Justice, Washington, DC.

ORD J.K. and GETIS A. (1995), « Local Spatial Autocorrelation Statistics : Distributional Issues and an Application », Geographical Analysis, 27, pp. 286-306.

RATCLIFFE J.H. (2000), « Aoristic analysis : the spatial interpretation of unspecific temporal events », Int. J, Geographical Information Science, 14, pp. 669-679.

SHERMAN L.W. (1995), « Hot spots of crime and criminal careers of places », in ECK J.E. and WEISBURD D. (eds.), Crime and Place, Criminal Justice Press, Monsey, NY.

\section{NOTES}

1. Zie o.a. Clarke (1997). Gegevens met betrekking tot de diefstallen en inbraken in het arrondissement Turnhout bevestigen dit enigszins : $50 \%$ van de opgehelderde diefstallen is gepleegd door $7 \%$ van de gekende daders terwijl $50 \%$ van de vastgestelde woninginbraken is gepleegd in $5 \%$ van het totale stratenbestand. 
2. Bron : Politioneel Informatie Systeem (POLIS), het geautomatiseerd registratiesysteem van processen-verbaal van de Rijkswacht.

3. Bron bevolkingsgegevens : Nationaal Instituut voor de Statistiek (NIS) (d.d. 1/1/2000).

4. Zoals bepaald door PointNet, een product van TeleAtlas.

5. Zie website www.bigfoot.com/ jerry.ratcliffe.

6. Gelezen in CRIMEMAP, the Crime Mapping Research Center's listserv.

\section{RÉSUMÉS}

Verschillende technieken voor het bepalen van criminele « hot spots " staan ter beschikking van criminologen en strategisch analisten bij politiediensten. Dit artikel geeft een overzicht van een aantal van deze technieken : het bestuderen van puntenkaarten, symboolkaarten en choropleten, clusteranalyse, local indicators of spatial association (LISA) en rasteranalyse. De praktische toepassing van elke techniek bij een fenomeenanalyse woninginbraken in het arrondissement Turnhout geeft inzicht in de voor- en nadelen van elke techniek voor het gebruik ervan bij politiediensten. We besluiten dat de onderzoeker ook bij de meer statistische methodes voor het bepalen van hot spots een grote invloed heeft op het resultaat. Daarnaast is het belangrijk dat de hoge concentratie van criminele feiten ook op voldoende wijze kan worden verklaard zodat een probleemgerichte aanpak mogelijk wordt.

Different techniques are available for the criminologists and strategic analysts in police services to determine the criminal «hot spots». This article gives an overview of some of those techniques : dot maps, symbol maps and choropleths, cluster analysis, local indicators of spatial association (LISA), raster analysis. The practical application of each technique on the occasion of the analysis of the house breaking phenomenon in the arrondissement of Turnhout gives an idea of the pros and cons of each technique when used by police services. We conclude that, even with the more statistical methods, the examiner has a considerable influence on the result when determining hot spots. Moreover the high concentration of criminal facts should also be explained in a satisfactory way so that a problem-centered apprehension becomes possible.

\section{INDEX}

Keywords : criminality, hot spots, spatial concentration, strategic analysis

Trefwoorden criminaliteit, hot spots, ruimtelijke concentratie, strategische analyse

\section{AUTEUR}

\section{ROBBIE HEREMANS}

Strategisch Analist, Federale Politie CSD Turnhout, Noord-Brabantlaan 70, 2300 Turnhout 